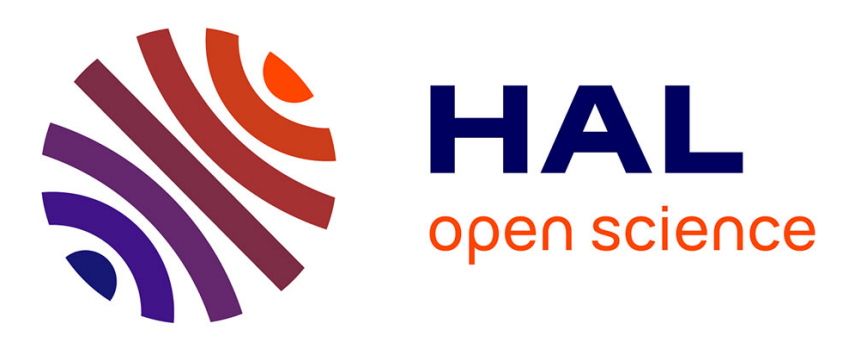

\title{
State-building and the Management of Diversity in India (Thirteenth to Seventeenth Centuries)
}

\author{
Corinne Lefèvre
}

\section{To cite this version:}

Corinne Lefèvre. State-building and the Management of Diversity in India (Thirteenth to Seventeenth Centuries). Medieval History Journal, 2014, 16 (2), pp.425-447. 10.1177/0971945813514907 . halshs01955988

\section{HAL Id: halshs-01955988 \\ https://shs.hal.science/halshs-01955988}

Submitted on 7 Jan 2020

HAL is a multi-disciplinary open access archive for the deposit and dissemination of scientific research documents, whether they are published or not. The documents may come from teaching and research institutions in France or abroad, or from public or private research centers.
L'archive ouverte pluridisciplinaire HAL, est destinée au dépôt et à la diffusion de documents scientifiques de niveau recherche, publiés ou non, émanant des établissements d'enseignement et de recherche français ou étrangers, des laboratoires publics ou privés. 


\section{The Medieval History Journal}

State-building and the Management of Diversity in India (Thirteenth to Seventeenth Centuries)

Corinne Lefèvre

The Medieval History Journal 2013 16: 425

DOI: $10.1177 / 0971945813514907$

The online version of this article can be found at:

http://mhj.sagepub.com/content/16/2/425

\section{Published by:}

(3)SAGE

http://www.sagepublications.com

Additional services and information for The Medieval History Journal can be found at:

Email Alerts: http://mhj.sagepub.com/cgi/alerts

Subscriptions: http://mhj.sagepub.com/subscriptions

Reprints: http://www.sagepub.com/journalsReprints.nav

Permissions: http://www.sagepub.com/journalsPermissions.nav

Citations: http://mhj.sagepub.com/content/16/2/425.refs.html

>> Version of Record - Mar 20, 2014

What is This? 


\title{
State-building and the Management of Diversity in India (Tfirteenth to Seventeentfi Centuries)
}

\author{
Corinne Lefèvre*
}

How has political diversity - and, first of all, administrative and institutional diversity-been handled within the succeeding polities that prevailed in the Indian subcontinent from 1200 to 1700 ? In order to provide the nonspecialist reader with a first insight into this complex question, the present article opens with a presentation of the sources available for reconstructing the administrative organisation and functioning of medieval and early modern Indian polities. Despite the fragmentary and biased nature of the information they provide, these sources (mainly epigraphic materials and narrative texts) have often been elevated to the rank of a solid substratum that allowed for the development of highly sophisticated yet antagonistic analyses of both the nature and the working of the Indian state in pre-British times. Besides a strong focus on the question of centralisation, most of these analyses have also long been marred by an implicit but ever-present Western point of comparison. From the middle of the 1980s, however, a number of voices have argued in favour of an alternative approach that would value both the processual character of state-and institution-building and its ideological dimension while stressing at the same time the need to take into account the diversity of the forms assumed by this process in the various regions that came to constitute a given polity and to pay more attention to the wide range of actors involved in state-formation and to the latter's political cultures. Taking its cue from these non-aligned or revisionist studies, as they are often termed, the last part of the essay shifts from the purely institutional perspective presiding over the first and largely historiographical section and proposes to examine instead the politics of

*Research fellow, CNRS, Centre for South Asian Studies (CNRS-EHESS), Paris, France.

The Medieval History Journal, 16,2 (2013): 425-447

SAGE Publications Los Angeles/London/New Delfi/Singapore/Wasfington DC DOI: $10.1177 / 0971945813514907$ 
diversity that were theorised and implemented by pre-colonial South Asian dynasties as well as the way these politics were perceived and handled by those who bore their brunt most directly, that is to say the subordinate functional elites.

Just like Europe, India was not a culturally, religiously, ethnically or politically unified entity in the period from the thirteenth to the seventeenth century. In contrast to Europe, however, India presented a relatively homogeneous picture where overarching political institutions were concerned. There was, for instance, nothing like the so-called maritime Republics of the Italian peninsula: even the flourishing port-city of Calicut where Vasco da Gama landed in 1498 was at the hands of a royal dynasty, that of the celebrated Zamorins. Kingship, in other words, was everywhere the preferred supra-local political institution. Significant diversity was located in the extent of the territories controlled (from a city and its hinterland to imperial formations spanning several regions) and more importantly, in the nature of the relationship(s) established between the monarch, his agents and the localities of his dominions. Precisely this 'diversity from within' is what I want to survey here, in consonance with the broad comparative approach lying at the root of the present volume.

How then has political diversity - and first of all administrative and institutional diversity - been handled within the succeeding polities that prevailed in the Indian subcontinent from 1200 to 1700 ? This is an especially demanding task for a number of reasons that need to be analysed in order to clear the ground for further reflection, but also to provide the readers who are not familiar with Indian history with valid insights with regard to the state of the art of politics.

\section{Where Do We Speak From? A Review of the Available Sources}

First among these reasons is the nature of the sources available for reconstructing the administrative organisation and functioning of medieval and early modern Indian polities. For, in contrast to his European colleague, the scholar investigating the political history of pre-colonial South Asia has no extensive institutional archives, such as fiscal and judicial registers, to rely on: except for various regions at the very end of the period under examination (the Deccan Sultanates in the wake of their absorption by

- The Medieval History Journal, 16, 2 (2013): 425-447 
the Mughals during the second half of the seventeenth century, or the eighteenth-century Maratha polity for instance), ${ }^{1}$ all we have access to are, at best, dispersed collections of administrative documents and correspondence as well as revenue manuals. And this does not only hold true for small regional kingdoms such as the Kakatiya realm that dominated the Andhra country during a long thirteenth century. ${ }^{2}$ It also applies to a large extent to the giant Mughal Empire, which at the height of its extension at the end of the seventeenth century had become quasi-coterminous with the subcontinent. So, what types of records have the political historians of pre-colonial India traditionally relied upon? In answering this question, I will focus more particularly on three polities which, because of their transregional dimensions and embedded diversity - be it cultural, religious, ethnical or political, will be at the core of this essay: the Delhi Sultanate, Vijayanagara and the Mughal Empire.

Very broadly speaking, the materials shedding light on the institutional arrangements and developments of these kingdoms may be said to be of two great types. Chronologically, the first are epigraphic materials, which, until the thirteenth century in the north and the fourteenth century in the south, constituted the largest corpus available. Whereas inscriptions have never loomed large in the historiography of Indo-Islamic polities, they have long held the high ground in the case of Vijayanagara: historians have relied heavily on the donations they recorded - chiefly donations to Brahmans, temples and other religious communities - in order to exhume the institutional structures of the kingdom, mainly through a tracking of recurrent administrative terminology. Even though the groups represented in the epigraphic materials included a wide range of political actors-first among whom were kings and subordinate warrior chiefs - and therefore allow a glimpse into several of Vijayanagara's administrative features, contemporary inscriptions did not, however, constitute political records per se.

The second major type of sources that have been tapped in order to understand how Indian pre-colonial polities actually worked are narrative texts. Foremost among these are kingly sponsored chronicles

\footnotetext{
${ }^{1}$ For an in-depth study of Deccani administration during this period, see Richards, Mughal Administration; for accounts of the Maratha polity based on documents preserved in the Pune Daftar or the Bharat Itihas Samshodak Mandal, see inter alia Gordon, Marathas, Marauders and Wink, Land and Sovereignty in India.

${ }^{2}$ On the Kakatiyas, see Talbot, Precolonial India in Practice.
} 
whose purport was the glorification of the regime in general and of the monarch who patronised the text in particular. Most chronicles of this kind followed a chronological framework and included information about the technologies of governance designed by the ruler and his entourage. In contrast to these texts, which were meant to be read as (but were not) factual accounts of events, works belonging to the genre of normative literature presented the reader with the ideal principles according to which society should be organised and governed. They were works of advice submitted by members of the elite to the ruling monarchs or, more rarely, reflections on the business of kingship composed by the rulers themselves. Although such narrative texts have been mostly associated with the Delhi Sultanate and the Mughal Empire, they are also available to the historian of Vijayanagara: suffice it to mention here the lengthy section on political ethics (raja-niti) included in the Amuktamalyada (The Woman Who Gives a Garland Already Worn), a major Telugu work by the famous Tuluva ruler Krishnadevaraya (r. 1509-1529), or the Achyutarayabhyudayam (The Rise of Achyutaraya), a biography of his successor Achyutaraya (r. 1529-1542). ${ }^{3}$

Travel accounts constitute yet another category of narrative texts that have extensively been used by historians to make sense of the nature and organisation of medieval and early modern Indian polities, all the more so because the authors of these travelogues made a point of offering their audience a clear and comprehensive account of the political customs of such exotic kingdoms. In this respect, one should keep in mind the historiographical importance acquired by such texts as the fourteenthcentury account of the Moroccan Ibn Battuta on the Delhi Sultanate, the sixteenth-century descriptions of Vijayanagara by the Portuguese Domingo Paes and Fernão Nunes or the report by the French François Bernier on late seventeenth-century Mughal India. The latter is a particular case in point. As a matter of fact, Bernier's characterisation of the empire founded by Babur (r. 1526-1530) as a highly predatory state that denied property rights to its denizens and left the peasantry with barely enough to survive was to become tremendously influential in the writings of colonial and post-colonial historians such as William H. Moreland and Irfan Habib. ${ }^{4}$

\footnotetext{
${ }^{3}$ For a recent re-examination and translation of the Amuktamalyada's Niti section, see Narayana Rao, Shulman and Subrahmanyam, 'A New Imperial Idiom in the Sixteenth Century'.

${ }^{4}$ For a demonstration of this point, see Alam and Subrahmanyam, 'Introduction'.
}

- The Medieval History Journal, 16, 2 (2013): 425-447 
What comes out clearly from this, admittedly, cursory review of the sources generally summoned for the study of pre-colonial South Asian polities is the fragmentary and biased nature of the information they provide where actual political functioning is concerned. Paradoxically, however, these same sources have been elevated by many to the rank of a solid substratum that allowed for the development of highly sophisticated

yet antagonistic analyses of both the nature and the working of the Indian state in pre-British times. These historiographical developments, it will be argued in the following pages, are another reason why thinking about politico-institutional diversity and its management stands today as a challenging task for the historian of South Asia.

\section{The Question of Politico-institutional Diversity in the Historiography of Indian Pre-colonial States}

When envisioned from the perspective of political institutions, the task allotted to me by the editors of the present volume, the question of the handling of diversity in a given polity may be said to boil down to that of the degree of centralisation and unification achieved by that same polity. In other words, to what extent, if at all, were the monarch and his agents able to effectively control all the territories that had come under their domination and to impose a uniform pattern of administration over these territories? The answers given to this question by many historians resulted in the emergence of an enduring dividing line between two groups whose constituents shared, however, little else than an implicit common understanding of the administrative and fiscal reach of the Indian pre-colonial kingdoms. In addition, this understanding has, more often than not, been marred to no small extent by an implicit but ever-present Western point of comparison: the modern European state, especially its regional incarnation as the British Raj, has long constituted the horizon against which the history of medieval and early modern South Asian polities has been (wilfully or not) thought and constructed. A number of scholars even went as far as to argue that the subcontinent had housed no state to speak of before the nineteenth century-an extreme position provocatively alluded to in a recent essay on the subject. ${ }^{5}$

\footnotetext{
${ }^{5}$ Kolff, 'A Millennium of Stateless Indian History?'
}

The Medieval History Journal, 16, 2 (2013): 425-447 


\section{Overcoming Politico-institutional Diversity: The Travails of the Centralising State}

On one side of the historiographical demarcation line mentioned above, one may identify a first group of scholars who ascribed to the states under review a degree of centralisation high enough to have resulted in the effective eradication of internal administrative diversity. Following the typology proposed by Hermann Kulke in the introductory section of his edited volume on The State in India ${ }^{6}$ one might include in this first group proponents of two models which, beyond their differences, bore the heavy stamp of colonial scholarship: on the one hand, the 'Indian historiographical model' (also variously designated as 'imperial' or 'bureaucratic') — of which the publications of K.A. Nilakantha Sastri on South India or the works of several historians of Allahabad University like Beni Prasad provide good examples; ${ }^{7}$ and, on the other, the Marxist model of oriental despotism and of the Asiatic mode of production. The handling of the Mughal case at the hands of the so-called Aligarh school of Marxist inspiration is certainly the best example of this second line of interpretation as far as the sophistication and the enduring character of the argument is concerned. ${ }^{8}$ According to its best-known representative Irfan Habib, the Mughal state succeeded in creating and promoting a series of systems which uniformly applied to all imperial territories from the end of the sixteenth century onwards: ${ }^{9}$ first, a pervasive fiscal system centred on the rigorous measurement of land and collection of agrarian revenue, and generally known as the zabt system, a Persian word referring to the act of seizing; second, a monetary system based on a gold-silver-copper trimetallism (the silver rupiya being supported by the gold muhr and the copper dam); third, a hierarchical system regulating the relations

\footnotetext{
${ }^{6}$ Kulke, 'Introduction'. For another survey putting in perspective the historiographies of the pre-colonial states of South and Southeast Asia, see Ali, 'Connected Histories?'.

${ }^{7}$ See e.g. Sastri, The Colas on the eponymous dynasty who dominated South-Eastern India from the ninth to the end of the thirteenth-century, and Prasad, History of Jahangir for an analysis of the Mughal Empire during the first quarter of the seventeenth century. Prasad, A Few Suggestions is also especially significant of the close relationship between the historian's treatment of the Mughals and his reflections on the institutional future of post-independence India.

${ }^{8}$ The following presentation takes its cue from Subrahmanyam, 'The Mughal State', and Alam and Subrahmanyam, 'Introduction'.

${ }^{9}$ Among his many writings, see his magnum opus: Habib, The Agrarian System.
} 
between the emperor and the members of the military-administrative elite collectively called mansabdars or 'those who hold a rank'; and fourth, a revenue assignment system that provided for the remuneration of the mansabdars by conferring upon them jagirs, that is to say temporary fiscal rights over a specified territory. Among other things, such a vision of the Mughal state implied that locally rooted chieftains better known as zamindars had been successfully deprived of their erstwhile political agency, leaving the peasantry face to face with the king's men.

Despite the fact that the historiographical models reviewed so far were underpinned by widely different ideological premises and conveyed contrasting views on state centralisation (a step towards modernity for the former, an instrument of increased oppression for the latter), the partisans of both approaches shared a common belief in the strong-if not absolute-nature of the power exercised by pre-colonial Indian rulers. The latter were, moreover, seen as having successfully equipped themselves with an efficient and hierarchically organised administration enabling them to secure vast revenues through the wide-scale collection of agrarian surplus.

\section{Tales of Failed Unifications: Feudal and Segmentary States}

On the other side of the historiographical dividing line delineated above were a number of scholars who considered that the administrative authority of the king and of his agents did not extend beyond the core territories surrounding the capital while the bulk of the kingdom remained in the hands of highly autonomous warlords whose relation with the centre ranged, according to formulations, from the regular payment of a tribute to the mere acknowledgement of the ritual sovereignty of the monarch. Relying once more on the typology elaborated by Kulke, such a vision of Indian pre-colonial states as having failed to achieve a high degree of political integration may be said to have been shared by the advocates of the Marxist-influenced model of Indian feudalism, ${ }^{10}$ the proponents of the segmentary state model that was originally

${ }^{10}$ Chapters 9 and 10 of 'Feudalism from Above' and 'Feudalism from Below' of Kosambi, An Introduction constituted the first attempt to define Indian feudalism; a decade later, Sharma, Indian Feudalism became the reference work on the subject. For an overview of the historiographical debate that ensued from these publications, see Byres and Mukhia, Feudalism and Non-European Societies.

The Medieval History Journal, 16, 2 (2013): 425-447 
developed by the anthropologist Aidan Southall in relation to the Alur society of eastern Africa and, ${ }^{11}$ to a lesser degree, by the adherents of the Weberian 'patrimonial-bureaucratic state' model. ${ }^{12}$ Among all these formulations, the segmentary state was certainly the one that carried the idea of decentralisation the furthest as vividly shown, in particular, by Burton Stein's analysis of Vijayanagara in his Peasant State and Society in Medieval South India published in 1980. According to David Shulman who aptly summarized Stein's reflections on the subject, the main features of the segmentary state were as follows:

a) a relatively weak centre whose control diminishes consistently with distance, so that one finds a series of relatively autonomous peripheral centres;

b) a tendency for these peripheral centres to 'replicate' the structure of authority evident in the major centre;

c) a pyramid-like organisation of the socio-political segments in relation to the central authority [...];

d) a ritual or symbolic hegemony that replaces effective political control as a major integrating force in the polity;

e) a dynamic, shifting, fluctuating system of relations between the various segments, the more peripheral of which can easily switch their allegiance. ${ }^{13}$

Burton Stein's assimilation of Vijayanagara to the segmentary state model represents, it is true, only one moment of his constantly evolving reflection on that polity, ${ }^{14}$ and its importance should therefore not be overemphasised. Still, the characterisation of Vijayanagara as a kingdom where local territories were not administrative regions nor local administrators bureaucratic agents emanating from the centre and where

${ }^{11}$ See Southall, Alur Society for the original formulation, and Southall, 'The Segmentary State in Africa and Asia' for its later extension to South Asia.

${ }^{12}$ Weber's influence is most vividly felt in Blake, Shahjahanabad where the Mughal Empire is credited with a strong patrimonial administration at the centre which, however, extended only temporarily beyond the core area through increased military and administrative control. As a whole, then, Blake's Mughal state lacked political integration and had to fight ubiquitous centrifugal tendencies.

${ }^{13}$ Shulman, The King and the Clown: 18-19.

${ }^{14}$ See Subrahmanyam, 'Agreeing to Disagree'. 
fiscal flows between the regions and the centre were, at best, episodic gives to the readers unfamiliar with Indian history a better idea of the very wide range of external models that have been applied to South Asian pre-colonial polities.

Be it as it may, on both sides of the historiographical demarcation line, the management of administrative diversity tended to become a somewhat irrelevant question because such diversity was either considered to have been successfully erased in the years following the foundation of the new polity or, on the contrary, was thought to constitute a permanent feature the monarch was powerless to overcome.

\section{Taking a Kaleidoscopic View of South Asian Pre-colonial Polities}

From the middle of 1980s, however, a number of voices have risen against such monolithic and often structuralist understandings of South Asian polities, arguing instead in favour of an approach that would value both the processual character of state- and institution-building and its ideological dimension. Besides, these non-aligned or revisionist studies, as they are often termed, have stressed the need to take into account the diversity of the forms assumed by this process in the various regions that came to constitute a given polity and to pay more attention to the wide range of actors involved in state-formation and to the latter's political cultures. In the case of the Delhi Sultanate, Sunil Kumar has demonstrated, for instance, how politico-administrative integration actually proceeded in fits and starts — both at spatial and chronological levels — rather than linearly. ${ }^{15}$ Whereas the penetration of the Delhi Sultanate at a local level had long been associated with the administrative, fiscal and monetary reforms Ala-ud-din Khalji (r. 1296-1316) introduced circa 1300, Kumar-basing himself on a wider range of sources than those traditionally used (including Sufi literature, numismatic, epigraphic and architectural materials) as well as on a reading against the grain of official chronicles - relates it instead to the three decades that followed the death of Shams-ud-din Iltutmish

\footnotetext{
${ }^{15}$ The following development is based on Kumar, The Emergence of the Delhi Sultanate. For other examples of such an approach, see: Chattopadhyaya, The Making of Early Medieval India on early medieval Rajput political formations; Kulke, Kings and Cults for a sample of his contributions on the Gajapatis of Orissa; Alam, The Crisis of Empire, and Singh, Region and Empire on the Mughal case.
}

The Medieval History Journal, 16, 2 (2013): 425-447 
(r. 1210-36) in 1236. Significantly enough, these years were one of the most troubled periods of the history of the sultanate: they witnessed both a dramatic contraction of the regions controlled by the sultan and incessant power conflicts between Iltutmish's now virtually autonomous military slaves or bandagan (singular, banda). In order to withstand the challenge of their fellow competitors and of sultanate forces, these Shamsi bandagan strove to establish deeper roots in the core territories of the sultanate they had come to control, most notably through alliances with local chieftains (or Ranas) and their subordinates. And according to Kumar, it is precisely in these Shamsis' efforts to implicate their territories into the politics and economy of their local contexts that the origins of the sultanate's penetration into the countryside are to be located: for the Shamsis' entrenchment not only took them to regions where the sultanate armies had never been before; once a measure of central authority was restored under Balban (r. 1266-1287), the necessity to neutralize the entrenched Shamsis also imposed that the chieftains with whom they had allied be destroyed or displaced and that direct sultanate administration be established on those territories.

This last example brings to light the benefits of considering the question of the handling of politico-institutional diversity from the point of view of the widest possible range of historical agents. Let the reader not be misled: this is not an attempt to examine state-building from below-an approach that has recently been promoted by a number of historians of Europe.$^{16}$ Whatever the benefits of a perspective from below, the available materials on pre-colonial South Asia simply deny such a possibility to the scholar: it is indeed no accident that the Subaltern Studies Collective failed to leave its mark on the medieval and early modern (political) history of India. ${ }^{17}$ Despite these limitations, the socio-cultural lead is the one I will follow in the second part of this essay, shifting as a result from the purely institutional perspective that has presided over the first and largely historiographical section. For, although technologies of governance are an important subject of study in themselves, one should keep in mind that they did not exist in abstracta but were elaborated, conveyed and implemented by_and therefore, at least originally, linked to-specific communities

\footnotetext{
${ }^{16}$ See the contributions gathered in Blockmans, Holenstein and Mathieu, Empowering Interactions.

${ }^{17}$ For two isolated forays, see, however, Bhadra, 'Two Frontier Uprisings in Mughal India'; and Mayaram, Against History, Against State.
}

- The Medieval History Journal, 16, 2 (2013): 425-447 
or groups who shared what may be called a common political culture. In that sense, the examination of the management of politico-institutional diversity should not be disconnected from that of the handling of the different groups carrying these various political traditions with them. Here is, in other words, how one could reformulate the question raised by the editors of the present volume: what were the politics of diversity that were theorised and implemented by South Asian dynasties between the thirteenth and the seventeenth century? And how were these politics perceived and handled by those who bore their brunt most directly, that is to say the subordinate functional elites? ${ }^{18}$

\section{Politics of Diversity: The Royal Prism}

Let us start, then, by reviewing two very different types of royal attitudes vis-à-vis the diversity of populations and political cultures that pre-colonial South Asian kingdoms came to encompass in the process of their construction and expansion.

\section{Case 1: Cultivating Diversity}

A first set of attitudes can be subsumed under the caption of 'cultivating diversity' and may be considered the most common handling pattern amongst the transregional polities under review. Whereas this has long been recognised to be the case of the Mughal Empire and of the Delhi Sultanate's offshoots in Bengal and in the Deccan, it is only quite recently that Vijayanagara has come to be seen in this light, and it is therefore this particular polity that will be used here as a case study.

As hinted above, Vijayanagara has long been considered a kingdom cultivating uniformity and singularity with regard to both ideology and political practices: it has been described as an essentially Hindu state whose very foundation and increasing militaristic orientation were spurred by the need to preserve the Hindu political and cultural order in the South against the expansion of Islam in the region which the troops of the Delhi, Bahmani and then the fragmented Deccan Sultanates successively incarnated. While it is true that the rulers of Vijayanagara sought to portray themselves as dharmic

${ }^{18}$ Even if religious actors - be they temples, monasteries, priests, ulama or leaders of Sufi movements - played no small part in the shaping and implementation of South Asian politics of diversity, the focus will be here on military and administrative elites.

The Medieval History Journal, 16, 2 (2013): 425-447 • 
kings (protecting the traditional socio-religious order), sponsored Brahmins and associated with a number of deities (most notably Virupaksha, a form of Shiva, and Rama, the seventh incarnation of Vishnu), a variety of recent studies have shown that the constant interaction with the Islamic worldboth within the subcontinent and beyond - did not result in the rejection of the alterity it represented but, on the contrary, in the selective adoption of some of its features. Most interestingly for the present perspective, such a process of appropriation concerned primarily the secular political sphere where it operated at both a practical and symbolic level. ${ }^{19}$

In the first domain, best known examples include the recruitment, from the middle of the fifteenth century onwards, of a considerable number of Turkic mercenaries who had previously been employed by the Deccan sultans and whose combined expertise in cavalry and archery techniques were highly valued in the context of the ongoing modernisation of the Vijayanagara army. Even if it is a more debated issue, the awarding of nayamkara tenures to Nayakas (a title referring to military leaders who also often discharged civilian functions) may additionally have been modelled on the Islamicate system of administration through iqta (assignment of the right to collect land revenue in return for military service) which was introduced in India by the Delhi Sultanate. ${ }^{20}$ In the symbolic domain, the research conducted on Vijayanagara's material culture by scholars such as Phillip Wagoner and George Michell has emphasised that the kingdom's rulers and elites not only came to master the Islamicate political and cultural idiom to a high degree but also made a sophisticated use of it. ${ }^{21}$ This is most vividly seen in titling practices - the Vijayanagara emperors adopted the title of Hindu-raya-suratrana or 'Sultan among Hindu kings' as early as 1352 - as well as in the areas of architecture and clothing.

Thus, whereas religious structures (including mosques) were systematically built according to Indic traditional styles, buildings housing court rituals or used for administrative purposes bore the stamp - both in their structure and decoration - of Islamic architecture. A similar dichotomy may also be detected in the sphere of sartorial codes:

${ }^{19}$ The following development is based on Wagoner, 'Harihara, Bukka, and the Sultan': 314-18.

${ }^{20}$ For further details on these two related points, see ibid.; Wagoner, 'Fortuitous Convergences'; and Eaton, 'The Articulation of Islamic Space': 160-66.

${ }^{21}$ See e.g. Wagoner, 'Sultan among Hindu Kings'; Michell, The Vijayanagara Courtly Style.

- The Medieval History Journal, 16, 2 (2013): 425-447 
Vijayanagara's monarchs and courtiers wore traditional South Indian garb when engaged in a Hindu religious activity or in a domestic setting, but opted for an Islamic style of dress for formal public audiences. As rightly argued by Wagoner, the fact that the use of the Islamic politico-cultural idiom was essentially public and restricted to secular and courtly settings points to its adoption by the local Indic elite as 'a means of effecting their symbolic participation in the more universal culture of Islam, thereby enhancing their political status and credibility in the eyes of the other participants in the Islamicate cultural system' ${ }^{22}$

The simultaneous cultivation of Indic and Islamic languages and technologies of power by the rulers of Vijayanagara is certainly a point that deserves the attention it has received in recent years. It should not, however, obscure the existence of other levels of diversity within the polity: what about, for instance, the management of the various regional and linguistic communities - Telugu, Kannada and Tamil-composing the local elite? Inscriptions have provided valuable prosopographical data on the personnel active in, say, the Tamil or the Andhra country, but additional research needs to be done about the more general pattern of incorporation that lay behind these postings and its possible ideological underpinnings. ${ }^{23}$ The same holds true for the articulation by the functional elites of their regional affiliation with their newly acquired imperial identity: if Krishnadevaraya's self-presentation in the Amuktamalyada as a Kannada monarch dedicating his book to a Telugu god-cum-king is any indication, ${ }^{24}$ such articulations were fraught with tensions.

\section{Case 2: Promoting Uniformity}

The second case study takes the reader to the Delhi Sultanate and to an altogether different type of royal attitudes towards diversity. The Persian literati writing for the successive sultans have done their best to bequeath to posterity an image of these men as outstanding commanders of a unified Muslim community struggling against the assaults of the

${ }^{22}$ Wagoner, 'Harihara, Bukka, and the Sultan': 316.

${ }^{23}$ On Tamil Nadu, compare Karashima, Towards a New Formation with Narayana Rao, Shulman and Subrahmanyam, Symbols of Substance: especially chapter 2; for the Andhra country, see Talbot, 'The Nāyakas of Vijayanagara Andhra'.

${ }^{24}$ Narayana Rao, Shulman and Subrahmanyam, 'A New Imperial Idiom in the Sixteenth Century'. For a recent, epigraphically based attempt to explore Nayaka political subjectivity under the rubric of kinship, see Chekuri, "Fathers" and "Sons". 
Mongol invaders (the outside enemy) and striving to extend the frontiers of the Dar-ul-Islam at the expense of the Hindu kafirs (or infidels, the enemy from within). Although it has been convincingly argued that such a characterisation deserved to be nuanced to a considerable extent, ${ }^{25}$ it cannot be ascribed solely to the polishing effect of the chroniclers' qalam. The violence assumed by the management of diversity in the sultanate - particularly during its initial phase - can in fact hardly be denied, especially in comparison with the Vijayanagara case discussed above or with the methods of acculturation douce (most notably through Persianisation) later favoured by the Mughals. The reference here is not to military campaigns but to the central role played by military slavery in the formation of the sultanate's elite corps. ${ }^{26}$

As is well-known, Muizz-ud-din Ghuri's (r. 1173-1206) North Indian campaigns and their consolidation under his commanders in the last decade of the twelfth century marked the advent of these mamluks or bandagan, as they were called in Persian, on the regional political stage as subordinates of the sultans but also, for the better part of the thirteenth century, as sultans themselves. These bandagan were typically non-Muslims who entered the service of the sultan as young boys either through purchase or as part of the booty acquired during military operations. Once the property of the sultan, they received an intensive military training as well as an introduction to the Islamic creed and to the social rules governing life at court - all of which were meant to turn them into loyal servants devoted to their new master's interests and creed or, in other words, to impart a brand new identity upon them. The bandagan were indeed expected to cut off all ties with the society they hailed from: the distant Central Asian steppe in the case of Mongols and Turks who constituted the majority of this slave elite, or closer local and regional polities for those who, like the famous Malik Kafur, ${ }^{27}$ were of Indian extraction. While nowadays it is generally accepted that such deracinated elites never entirely severed the bonds of solidarity with their native homes and erstwhile networks, it nonetheless remains true that the logic presiding over their incorporation

\footnotetext{
${ }^{25}$ Kumar, The Emergence of the Delhi Sultanate, especially Chapter 4.

${ }^{26}$ For a panoramic view of the role of slavery in South Asian history, see the contributions gathered in Chatterjee and Eaton, Slavery and South Asian History.

${ }^{27}$ Malik Kafur (d. 1316) was part of the large booty captured from Cambay in the wake of the Khalji conquest of Gujarat in 1299. As a eunuch slave of 'Ala'-ud-din Khalji, he became one of the leading military commanders of the sultanate.
}

- The Medieval History Journal, 16, 2 (2013): 425-447 
into the sultanate was one that aimed at erasing their original ethnic and religious diversity in order to promote the new rising 'Persianate Muslim order'. Interestingly enough, such a drive towards uniformity did not only concern the slave elements of the Sultanate's ruling class; it also affected, albeit at a very different level, the free commanders whose political culture did not conform to the officially-sponsored idiom.

As argued by Sunil Kumar, this was particularly the case of those frontier commanders who had a record of past service to the Mongols, the archenemy of the sultanate. ${ }^{28}$ Most famous amongst them were, rather ironically, Jalal-ud-din Khalji (r. 1290-1296) and Ghiyas-ud-din Tughluq (r. 1320-1324), founders of the respective Khalji and Tughluq dynasties: whereas the former had served as the Mongol commander of Binban (west of the Indus), the latter was a Qara'una Turk, a group closely associated with the Juchid-Golden Horde. Once at the head of the sultanate, these men introduced into its apparatus new administrative practices and rituals such as the ulagh postal relay system of Mongol origins, and the Turkic ghashiya royal ritual of procession. The steppe provenance of these innovations could, however, hardly be mentioned as such in official chronicles that purported to describe the sultans' implementation of Persian norms of governance and narrate their triumphs over the evil forces of the Mongols. In the case of the frontier commanders, then, it was the memory of the alternative traditions they represented and introduced in the sultanate, rather than the traditions themselves, which was the object of obliteration. Promoting uniformity was, to be sure, a common purpose of royal historiography which, in the case of the Delhi Sultanate, combined most effectively with homogenising administrative practices such as military slavery. This does not mean, of course, that diversity was thereby successfully eradicated - far from it; it simply complicated the task of twenty-first-century historians eager to recover it. Be that as it may, the Delhi Sultanate case unmistakably points to a very different pattern of handling diversity than the one promoted by Vijayanagara rayas and Mughal padshahs.

\section{Politics of Diversity: Elites' Ways of Talking Back}

In the concluding section of this essay, I propose to cast the net wider and to move the focus away from the head managers of political diversity - the kings and their closest associates - onto those whose alterity was thereby

\footnotetext{
${ }^{28}$ The following development is based on Kumar, 'The Ignored Elites'.
} 
handled, that is to say the subordinate elites. What were, in other words, the reactions of the functional elites to dynastic politics of diversity? Multiple ways of talking back were available to them, ranging from rejection to assimilation and including partial accommodation. These responses were, moreover, not frozen in time but evolved according to the fluctuations of the balance of power and of official ideology. Thanks to the relatively copious sub-imperial literature that has reached us, the reactions of the different groups that came to be included under the Mughal umbrella are certainly amongst the best known today and they will therefore constitute the focus of the following discussion on the subject. The Turco-Mongol and Rajput instances chosen for case study present the advantage of documenting the responses of members of the 'old' nobility - a term referring to the elite groups who arrived in India alongside with the Mughals - and of some of the new elements that were associated with the dynasty in the course of the expansion and consolidation of its power. ${ }^{29}$ Besides, these examples allow us to scrutinise two very different brands of political cultures the Mughals had to confront when building their empire.

\section{Case 1: Marginalisation and Rebellion}

The first brand considered here is the Turco-Mongol one. The Mughals being themselves of Central Asian origin, warriors and lords of the same background naturally held prime of place in the entourage of Babur, of his son Humayun (r. 1530-40, 1555-56), and of his grandson Akbar (r. 1556-1605) on the latter's accession to the throne. The primacy of the Turanis (the preferred designation of people hailing from Central Asia in Mughal sources) was not, however, without causing problems to the emperors in so far as the dominant political culture among this group valued a conception of collective sovereignty originating with Chingiz Khan (d. 1227) according to which the right to rule belonged to the lineage as a whole rather than to the individual figure of the monarch. ${ }^{30}$ Even though this Turco-Mongol tradition had been substantially altered by Timur (d. 1405)

\footnotetext{
${ }^{29}$ It also holds true of the Iranian and Afghan components of the Mughal elite, which are analysed in a similar perspective in Lefèvre, 'Pouvoir et noblesse dans l'empire moghol'.

${ }^{30}$ For two classical, albeit contrasted, accounts of the Turco-Mongol political tradition and its impact on early Mughal and Sur Northern India, see Tripathi, Some Aspects of Muslim Administration: 105-21, and Khan, 'The Turko-Mongol Theory of Kingship'.
}

- The Medieval History Journal, 16, 2 (2013): 425-447 
at the benefit of the ruler's authority, it was still thought of by his Mughal descendants as conducive to political fragmentation and, therefore, as an impediment to the strong central authority they wished to develop in their new dominions. This had indeed been bitterly experienced by Humayun whose failure to take up the challenge emanating from his nobility and siblings (especially his half-brother Mirza Kamran) resulted in the loss of his Indian possessions to the Afghan Sur dynasty for more than a decade.

Given his father's setbacks, one of Akbar's most pressing needs was to tighten his grip over the military-administrative elite, an objective he strove to achieve through the development of a three-pronged strategy: one aspect thereof was the diversification of the groups on which the dynasty had so far relied on for maintenance of order, and this implied the growing participation in the empire of Iranians, Indian Muslims or shaikhzadas as well as local Rajput chiefs and scribal elites such as Kayasthas and Khatris; another was the elaboration of a series of administrative instruments that were to ensure the transformation of this highly heterogeneous elite into a strictly hierarchised body of loyal servants to the empire; finally, the ideological formulations Akbar successively elaborated aimed at tightening the bonds between the monarch and his umara' (singular amir, a high-ranking dignitary) and at strengthening the latter's adhesion to the empire. The Central Asian elements of the nobility particularly resented the first two aspects of Akbar's strategy: while the emperor's cultivation of diversity threatened to undermine their erstwhile dominant position in the political arena, his development of administrative practices of control ran counter to the relative autonomy they were accustomed to. Unwilling to endorse the new orientations promoted by Akbar, different sections of this Central Asian elite launched far-reaching revolts in 1564-66 and again in 1580-82:31 in both cases, the rebels enlisted the support of Akbar's half-brother Mirza Muhammad Hakim (d. 1585) in whom they saw the rightful guardian of the Turco-Mongol political traditions they valued so much. ${ }^{32}$ Their protest movements, however, failed to succeed, and the Turani umara' had no choice but to accept the diminished position they had been assigned in the new order.

${ }^{31}$ For a brief account of both events, see Richards, The Mughal Empire: 16-18 and $40-41$.

${ }^{32}$ This has been argued previously by Subrahmanyam, 'The Mughal State': 298-99. For further details on the figure of Mirza Muhammad Hakim, see Subrahmanyam, 'A Note on the Kabul Kingdom'; and Faruqui, 'The Forgotten Prince'.

The Medieval History Journal, 16, 2 (2013): 425-447 
And yet, this did not mean that the alternative political culture they represented disappeared completely: projects of appanaging the empire between contending princes resurfaced regularly during the seventeenth century and the early eighteenth on occasion of princely rebellions and succession struggles. It has, for instance, been shown to be the case in the late 1650s (between Aurangzeb and his brother Murad) and, again, after Aurangzeb's death in 1707 (between Bahadur Shah and his brother A'zam Shah). ${ }^{33}$ The relatively late date of both events should not, however, lead one to reduce the latter to some kind of signal of the crumbling fortunes of the empire. As a matter of fact, in 1606- that is, only a year after the demise of Akbar who has long been credited with the eradication of the Turco-Mongol menace, his grandson Khusrau (d. 1622) rebelled against his reigning father Jahangir (r. 1605-27) with the idea of appropriating the ancient dominions of Mirza Muhammad Hakim in Kabul. ${ }^{34}$ Taken as a whole, these episodes clearly point to the resilience of Turco-Mongol political traditions (with their potentially disruptive effects on the empire) throughout the history of the dynasty. More generally, the handling of the Turani umara' at the hands of Babur and his successors is particularly instructive where the limits of the Mughal politics of diversity are concerned: cultivating difference within the ruling class obviously did not translate into equality of treatment for all its components.

\section{Case 2: Submission and Accommodation}

Whereas the Central Asian example has allowed the readers to apprehend the reaction of an old elite group who was rather adversely affected by the Mughal politics of diversity, the second case study takes them to the opposite side of the spectrum by considering the instance of the Rajputs. In contrast to the Turani umara', local Rajput warlords could claim no long-standing association with the Mughal rulers or a common politico-cultural background: initially at least, they were the local enemy who had to either be entreated into a subordinate association or else be crushed. From the 1560s onwards, most Rajput chieftains favoured the former solution, a substantial number of them moreover striking marital

${ }^{33}$ Subrahmanyam, 'The Mughal State': 300.

${ }^{34}$ This is borne out by several contemporary sources including Harawi, Tarikh-i Khan Jahani, vol. 2: 674, 684; and Jahangir, Jahangir Nama: 51, 56 and 84.

- The Medieval History Journal, 16, 2 (2013): 425-447 
alliances with the new ruling dynasty. ${ }^{35}$ In exchange for their submission, the Rajas recovered their ancestral holdings in the form of watan jagirs - over which, it should be emphasised, they retained a fair degree of administrative autonomy, including the collection of land revenue. The Rajputs were also progressively associated with the governance of the empire through the attribution of military and administrative charges in far-off provinces. For the many among them who did not rank high in the traditional hierarchy of Rajput little kingdoms, the subordinate alliance with the Mughals hence turned out to be a formidable springboard, endowing them with a greater amount of legitimacy vis-à-vis subordinate and rival clans and allowing them to reach far higher levels of wealth and power than those they could formerly have laid claim to. To mention but a few of the best-known examples in this domain: the Kachhwaha Raja Bharmal's (r. 1543-1573/74) hold over the Amber kingdom remained tenuous until his alliance with Akbar (1562) enabled him to secure his territories more firmly; the Hada Rao Surjan (d. 1585) was a mere subordinate to the Sisodiyas of Mewar until he surrendered the Ranthambhor fort to the Mughals in 1569; the Bundela Bir Singh Deo (r. 1605-1627), for his part, owed his accession to the throne of Orchha to Jahangir's backing - the latter a reward for the murder of Abu'l Fazl, Akbar's celebrated ideologue and friend. The Rajputs' active participation in the new Mughal order did not, however, require them to turn their back on their own political culture. True, on the one hand, they abided, as mansabdars, by the rules of imperial service which also happened to find a profound echo in their own warrior ethos. ${ }^{36}$ On the other hand, the higher position they gained under Mughal rule allowed them to rise above these local codes of behaviour and to present themselves as fully-fledged Rajas through the adoption of a series of lordly practices. Whether it be the conspicuous patronage of religious centres like Varanasi or Mathura, the commissioning of texts belonging to the mahakavya or courtly epic genre, or the sponsorship of architecture and of visual arts, such practices conspicuously point to the persistent centrality of Indic norms of royalty in the Rajputs' self-definition as Rajas. ${ }^{37}$ As has been demonstrated by a recent set of publications examining the literary

\footnotetext{
${ }^{35}$ For an exhaustive list of Mughal-Rajput marriages, see Taft, 'Honor and Alliance'.

${ }^{36}$ Ziegler, 'Some Notes'.

${ }^{37}$ This is argued in greater details in Talbot, 'Justifying Defeat'.
} 
works (in Sanskrit or in vernaculars) and the buildings patronised by the Hadas of Bundi, the Kachhwahas of Amber and the Bundelas of Orchha, Mughal paramountcy only played a minimal — if not accidental — role in the construction of the Rajas' legitimacy which the authors consistently formulated within the classical Sanskritic episteme of Hindu dharma and kingship. ${ }^{38}$ Furthermore, Mughal rulers were themselves incorporated in this episteme to a certain extent: in the texts composed at the behest of their subordinate allies, the padshahs were alternatively defined as chakravartins or 'turners of the wheel', described as having descended to earth as avataras, praised for their concern with dharma or compared to paragon figures of Indic royalty such as Rama. When seen from the Rajputs' perspective, then, the irruption of political diversity in the guise of the Mughals was handled through a double process of accommodation to the new order and of assimilation of its foremost representatives into an Indic Weltanschauung - an assimilation, or 'Hinduization', which was, however, only made possible by a shared conception of the monarch as a divinely sanctioned figure whose prime duty was to strike a durable balance between the different components of society.

As the Central Asian and Rajput examples clearly illustrate, the most disruptive effects of newly state-sponsored politics of diversity were not always located where one would have expected them to be. And this should certainly encourage scholars working on South Asian pre-colonial polities to diversify the vantage points from which the complex question of the management of political diversity has so far been considered: attention must certainly continue to be paid to the solutions favoured by the centre and to their evolution in time, but historical analysis should also seriously take into account the politico-cultural responses elaborated by the various warrior and scribal service groups who constituted the backbone of Indian kingdoms and empires from the thirteenth to the seventeenth centuries. ${ }^{39}$

\footnotetext{
${ }^{38}$ See ibid. on Rao Surjan Hada; Asher, 'The Architecture of Raja Man Singh' and Busch, 'Portrait of a Raja' on Raja Man Singh Kachhwaha (d. 1614); Busch, 'Literary Responses'; Pauwels, 'The Saint, the Warlord, and the Emperor' and Rothfarb, Orchha and Beyond on the Bundelas.

${ }^{39}$ Scribal groups have recently been the object of increased scholarly attention as illustrated by O'Hanlon and Washbrook, Munshis, Pandits and Record Keepers, a volume dedicated to the exploration of the scribes' social identities, group histories and role in a wide range of pre-colonial Indian polities.
}

- The Medieval History Journal, 16, 2 (2013): 425-447 


\section{State-6uilding and the Management of Diversity 445}

\section{References}

Alam, Muzaffar. 1986. The Crisis of Empire in Mughal North India: Awadh and the Punjab, 1707-1748, Delhi.

Alam, Muzaffar and Sanjay Subrahmanyam. 1998. 'Introduction', in Muzaffar Alam and Sanjay Subrahmanyam (eds), The Mughal State 1526-1750, Oxford: 1-71.

Ali, Daud. 2009. 'Connected Histories? Regional Historiography and the Theories of Cultural Contact Between Early South and Southeast Asia', in R. Michael Feener and Terenjit Sevea (eds), Islamic Connections: Muslim Societies in South and Southeast Asia, Singapore: 1-24.

Asher, Catherine B. 1992. 'The Architecture of Raja Man Singh: A Study of Sub-imperial Patronage', in Barbara Stoler Miller (ed.), The Powers of Art: Patronage in Indian Culture, Delhi: 183-201.

Bhadra, Gautam. 1983. 'Two Frontier Uprisings in Mughal India', in Ranajit Guha (ed.), Subaltern Studies No. 2: Writings on South Asian History and Society, Delhi: 43-59.

Blake, Stephen. 1991. Shahjahanabad: The Sovereign City in Mughal India, 1639-1739, Cambridge.

Blockmans, Wim, André Holenstein and Jon Mathieu in collaboration with Daniel Schläppi (eds). 2009. Empowering Interactions: Political Cultures and the Emergence of the State in Europe 1300-1900, Farnham.

Busch, Allison. 2012. 'Portrait of a Raja in a Badshah World: Amrit Rai's Biography of Man Singh (1585)', in Corinne Lefèvre and Ines G. Županov (eds), Cultural Dialogue in South Asia and Beyond: Narratives, Images and Community (16th-19th centuries). Special issue of the Journal of the Economic and Social History of the Orient, vol. 55(2-3): 287-328.

- 2005. 'Literary Responses to the Mughal Imperium: The Historical Poems of Keśavdās', South Asia Research, vol. 25(1): 31-54.

Byres, Terence J. and Harbans Mukhia (eds). 1985. Feudalism and Non-European Societies, London and Totowa (NJ).

Chatterjee, Indrani and Richard M. Eaton (eds). 2006. Slavery and South Asian History, Bloomington and Indianapolis.

Chattopadhyaya, Brajadulal. 1994. The Making of Early Medieval India, Delhi.

Chekuri, Christopher. 2012. "Fathers" and "Sons": Inscribing Self and Empire at Vijayanagara, Fifteenth and Sixteenth Centuries', The Medieval History Journal, vol. 15(1): 137-69.

Eaton, Richard M. 2000. 'The Articulation of Islamic Space in the Medieval Deccan', in Essays on Islam and Indian History, Delhi: 159-75.

Faruqui, Munis Daniyal. 2005. 'The Forgotten Prince: Mirza Hakim and the Formation of the Mughal Empire in India', Journal of the Economic and Social History of the Orient, vol. 48(4): 487-523.

Gordon, Stewart. 1994. Marathas, Marauders, and State Formation in Eighteenth-century India, Delhi.

Habib, Irfan. 1999[1963]. The Agrarian System of Mughal India, 1556-1707, Oxford.

Harawi, Khwaja Ni‘matullah. 1960. Tarikh-i Khan Jahani wa Makhzan-i Afghani, ed. S.M. Imamuddin, 2 vol., Dacca.

The Medieval History Journal, 16, 2 (2013): 425-447 
Jahangir, Nur-ud-din Muhammad. 1999. Jahangir Nama, trans. W.M. Thackston, Washington D.C. and New York.

Karashima, Noboru. 1992. Towards a New Formation: South Indian Society Under Vijayanagar Rule, Delhi.

Khan, Iqtidar Alam. 1972. 'The Turko-Mongol Theory of Kingship', Medieval India: A Miscellany, vol. 2: 8-18.

Kolff, Dirk. 2008. 'A Millennium of Stateless Indian History?', in Rajat Datta (ed.), Rethinking a Millennium: Perspectives on Indian History from the Eighth to the Eighteenth Centuries: Essays for Harbans Mukhia, Delhi: 51-67.

Kosambi, Damodar Dharmanand. 1956. An Introduction to the Study of Indian History, Mumbai.

Kulke, Hermann. 1995. Kings and Cults: State Formation and Legitimation in India and Southeast Asia, Delhi.

- 1993. 'Introduction: The Study of the State in Pre-Modern India', in Hermann Kulke (ed.), The State in India, 1000-1700, Oxford: 1-47.

Kumar, Sunil. 2009. 'The Ignored Elites: Turks, Mongols and a Persian Secretarial Class in the Early Delhi Sultanate', Modern Asian Studies, vol. 43(1): 45-77.

2007. The Emergence of the Delhi Sultanate 1192-1286, Delhi.

Lefèvre, Corinne. 2007. 'Pouvoir et noblesse dans l'empire moghol. Perspectives du règne de Jahāngīr (1605-1627)', Annales. Histoire, Sciences Sociales, vol. 62(6): 1287-1312.

Mayaram, Shail. 2003. Against History, Against State: Counter Perspectives from the Margins, New York.

Michell, George. 1992. The Vijayanagara Courtly Style: Incorporation and Synthesis in the Royal Architecture of Southern India, 15th-17th Centuries, Delhi.

Narayana Rao, Velcheru, David Shulman and Sanjay Subrahmanyam. 2011. 'A New Imperial Idiom in the Sixteenth Century: Krishnadevaraya and His Political Theory of Vijayanagara', in Sheldon Pollock (ed.), Forms of Knowledge in Early Modern Asia: Explorations in the Intellectual History of India and Tibet, 1500-1800, Durham and London: 69-111.

1992. Symbols of Substance: Court and State in Nāyaka Period Tamil Nadu, Delhi.

O'Hanlon, Polly and David Washbrook (eds). 2010. Munshis, Pandits and Record Keepers: Scribal Communities and Historical Change in India (special issue of the Indian Economic and Social History Review, vol. 47[4]).

Pauwels, Heidi. 2009. 'The Saint, the Warlord, and the Emperor: Discourses of Braj Bhakti and Bundelā Loyalty', Journal of the Economic and Social History of the Orient, vol. 52: $187-228$.

Prasad, Beni. 1928. A Few Suggestions on the Problem of the Indian Constitution, Allahabad.

- 1922. History of Jahangir, London.

Richards, John F. 2001[1995]. The Mughal Empire, Cambridge. 1975. Mughal Administration in Golconda, Oxford.

Rothfarb, Edward. 2012. Orchha and Beyond: Design at the Court of Raja Bir Singh Dev Bundela, Mumbai.

Sastri, Nilakantha and Kallidaikurichi Aiyah. 1955. The Colas, Madras.

Sharma, Ram Sharan. 1965. Indian Feudalism, c. 300-1200, Kolkata.

- The Medieval History Journal, 16, 2 (2013): 425-447 
Shulman, David. 1985. The King and the Clown in South Indian Myth and Poetry, Princeton.

Singh, Chetan. 1991. Region and Empire: Punjab in the Seventeenth Century, Delhi.

Southall, Aidan. 1988. 'The Segmentary State in Africa and Asia', Comparative Studies in Society and History, vol. 30(1): 52-82.

- 1956. Alur Society: A Study in Processes and Types of Domination, Cambridge.

Stein, Burton. 1980. Peasant State and Society in Medieval South India, Delhi.

Subrahmanyam, Sanjay. 1997. 'Agreeing to Disagree: Burton Stein on Vijayanagara', South Asia Research, vol. 17(2): 126-39.

. 1994. 'A Note on the Kabul Kingdom under Muhammad Hakim Mirza (1554-85)', La transmission du savoir dans le monde musulman périphérique, Lettre d'information, vol. 14: 89-101.

1992. 'The Mughal state-Structure or Process? Reflections on Recent Western Historiography', The Indian Economic and Social History Review, vol. 29(3): 291-321.

Taft, Frances H. 1994. 'Honor and Alliance: Reconsidering Mughal-Rajput Marriages', in Karine Schomer, Joan L. Erdman, Deryck O. Lodrick and Lloyd I. Rudolph (eds), The Idea of Rajasthan: Explorations in Regional Identity. Vol. 2: Institutions, Delhi: 217-41.

Talbot, Cynthia. 2012. 'Justifying Defeat: A Rajput Perspective on the Age of Akbar', in Corinne Lefèvre and Ines G. Županov (eds), Cultural Dialogue in South Asia and Beyond: Narratives, Images and Community (16th-19th centuries). Special issue of the Journal of the Economic and Social History of the Orient, vol. 55(2-3): 329-68.

- 2001a. Precolonial India in Practice: Society, Religion and Identity in Medieval Andhra, New York.

—. 2001b. 'The Nāyakas of Vijayanagara Andhra: A Preliminary Prosopography', in Kenneth Hall (ed.), Structure and Society in Early South India: Essays in Honour of Noboru Karashima, Delhi: 251-75.

Tripathi, Ram Prasad. 1959[1936]. Some Aspects of Muslim Administration, Allahabad.

Wagoner, Phillip. 2000. 'Harihara, Bukka, and the Sultan. The Delhi Sultanate in the Political Imagination of Vijayanagara', in David Gilmartin and Bruce B. Lawrence (eds), Beyond Turk and Hindu: Rethinking Religious Identities in Islamicate South Asia, Gainesville (Florida): 300-26.

1999. 'Fortuitous Convergences and Essential Ambiguities: Transcultural Political Elites in the Medieval Deccan', International Journal of Hindu Studies, vol. 3(3): 241-64.

1996. "Sultan among Hindu Kings": Dress, Titles, and the Islamicization of Hindu Culture at Vijayanagara', Journal of Asian Studies, vol. 55(4): 851-80.

Wink, Andre. 1986. Land and Sovereignty in India: Agrarian Society and Politics under the Eighteenth-century Maratha Svarajya, Cambridge.

Ziegler, Norman P. 1998 [1978]. 'Some Notes on Rajput Loyalties during the Mughal Period', in John F. Richards (ed.), Kingship and Authority in South Asia, Delhi: 242-84. 
